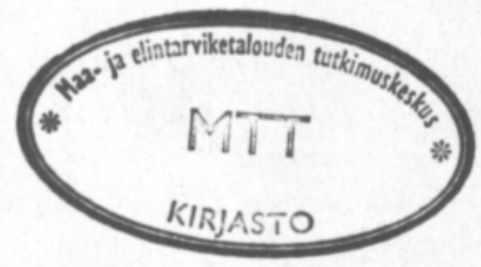

\title{
DDT, LINDANE AND ENDRIN IN SOME AGRICULTURAL SOILS IN FINLAND
}

\author{
Jorma RautapäÄ \\ Agricultural Research Centre, Department of Pest Investigation \\ Tikkurila, Finland \\ Hilkka Siltanen, Anna-Liisa Valta and Vejo Mattinen \\ State Institute of Agricultural Chemistry, Helsinki, Finland
}

Received September 4, 1972

\begin{abstract}
The residues of DDT and lindane were determined from 21 sugarbeet fields, and endrin was determined from the soil of 4 gardens. Previously, DDT and lindane have been used widely against sugarbeet pests, and endrin is used to control voles in gardens.

The DDT-content (o,p'DDT + p,p'DDT + DDE) of soil samples was in average $0.73 \mathrm{ppm}$ (minimum 0, maximum $2.35 \mathrm{ppm}$ ). The amount of DDE was about $5 \%$ of the joint total of o,p'DDT and p,p'DDT. About $21 \%$ (minimum $2 \%$, maximum $65 \%$ ) of the total amount of DDT applied to the field had remained at the time of taking samples.

The average lindane content of the soil was $0.08 \mathrm{ppm}$ (minimum 0.008 , maximum $0.8 \mathrm{ppm})$. Of the amount of lindane, which was known to have been applied to the soil, $5-100 \%$ had remained.

The average endrin content of samples was $0.12 \mathrm{ppm}$ (minimum 0 , maximum 0.25 ppm). From the total amount of endrin applied to the area, $0-55 \%$ was left.
\end{abstract}

According to published statistics the total amount of chlorinated hydrocarbon pesticides sold and used in Finland since 1953 is 402 tons active ingredient (see e.g. MarkKulA and Tirttanen 1969). This amount is $4.5 \%$ of the total quantity of all types of pesticides sold in that time.

The use of DDT was greatest in 1960-1962 when the sales corresponded to a total of about $10-12$ tons (a.i.) per year. One of the most important uses has been on sugarbeet, the most injurious species of which (Lygus rugulipennis Popp., Chaetocnema concinna Marsh., and Pegomyia betae (Curt.)) have usually been controlled with two applications of DDT in the beginning of the summer. In the 1950's DDT was used largely also for controlling pests in gardens. According to an unpublished study (Dr. agr. and for. Anna-Liisa Varis, personal communication), in 1965, 1967, and 1968 about $12 \%$ of the cultivated area for sugarbeet was treated with dusts containing DDT. The total area for sugerbeet has been some $15000-18000$ hectares, about 2000 hectares of this have been treated with DDT annually. The normal rate of application has been about 20 kilos of combined DDT and parathion dust per hectare and the vegetation has been treated twice. About 
2.5. kilos of DDT per hectare per year can be estimated to have reached the vegetation and the soil. In Finland DDf or other pesticides have not been mixed with soil in any larger amounts.

The seeds of Crucifergus plants have relatively often been treated with lindane against the Phytlotrela speeies. At the end of the 1960's seed treatment against the Lygus species was likewise started. The amount of lindane for sugarbeet has been 10 grams/kilo of seed, and for other plants $80-120$ grams/kilo. On the basis of this rate of application about 130 grams of lindane per hectare (a.i.) per year has reached the sugarbeet soil.

The use of endrin has been allowed only in gardens and forest nurseries in control against voles. The treatments have been done in autumn before the first snow. The total sale of endrin in 1953-1967 was about 4.4 tons (a.i.) (MarkKula and Tirttanen 1969).

According to new regulations the use of DDT, since August 31st, 1971, has been permitted only in treating forest saplings in nurseries. Lindane can only be used for the treatment of forest saplings, unprocessed wood, and the seeds and roots of field and garden plants. The use of endrin is only allowed in the control of voles on cultivations of forest tree saplings and forest nurseries.

The amount of pesticides in Finnish agricultural soil has not been previously studied. As the use of DDT, lindane and endrin has been quite common, soil samples were collected in autumn 1969 from areas where these pesticides had been used for a long time. Most of the samples were collected by the Sugarbeet Cultivation Research Centre and by the Agricultural Research Centre, Department of Horticulture. These institutions also gave information on the amounts and applications of pesticides in the studied areas. The samples were analysed in the State Institute of Agricultural Chemistry.

\section{MATERIAL}

The soil samples were collected during September and October in 1969. From the $20 \mathrm{~cm}$ top layer of the section to be studied samples of one kilo, which represented the area in the widest possible sense, were taken using an earth auger. The soil samples were kept in a temperature of about $-20^{\circ} \mathrm{C}$. The pesticides were analysed in autumn 1969 and in winter 1970. For most of the sections it was possible to interpret the treatments with considerable accuracy (see Table 3 ).

\section{ANALYTICAL PROCEDURES}

The soil samples, dried at room temperature, were extracted in Soxhlet with hexaneacetone $(9+1)$ for 16 hours. DDT, lindane and endrin were determinated by gas chromatograph with electron capture detector.

A p p a r a t u s : Pounding trough. Extraction apparatus, Soxhlet. Rotation-type vacuum evaporator, Büchi. Chromatographic column with stopcock, glass, diameter $2 \mathrm{~cm}$. Gas chromatograph: Varian Aerograph 1520 with EC-detector; metal column $(1,5 \mathrm{~m} \times 2,3 \mathrm{~mm}), 5 \%$ SE-30 on Chrom W, 60/80 mesh, AW, DMCS; glass column (1,5 m × $3 \mathrm{~mm}), 5 \%$ GE XE-60 on Chrom W, 60/80 mesh, AW, DMCS. Gas chromatograph: Perkin-Elmer with EC-detector; glass column $(1 \mathrm{~m} \times 3 \mathrm{~mm}), 4 \%$ Ethylene Glycol Adipate on Chrom W, 60/80 mesh, AW, DMCS. 
R e a g e n t s: Hexane, redistilled. Acetone, redistilled. Methylene chloride, redistilled. Sodium sulphate, anhydrous, Ph. Nord., dried at $130^{\circ} \mathrm{C}$ for two hours. Celite 545. Bolus Alba. Nuchar C $190 \mathrm{~N}$. Alumina, neutral, activity grade II. Chromatographic mixture: Mix thoroughly 8 parts of anhydrous sodium sulphate, 8 parts of Celite 545, 2 parts of Bolus Alba, 3 parts of Nuchar C $190 \mathrm{~N}$ and 6 parts of alumina, neutral, activity II.

Experimental: The soil samples were dried at room temperature for 48 hours, ground in a pounding trough and extracted as follows:

Experiment 1.50 to $100 \mathrm{~g}$ of soil was weighed in a beaker and $250 \mathrm{ml}$ of hexane-acetone $(9+1)$ was added. The mixture was mixed thoroughly with a glass rod and the beaker was set aside for overnight. The solution was decanted through a filter funnel, containing about $20 \mathrm{~g}$ of anhydrous sodium sulphate into a 1-liter evaporation flask. The mass was washed in the beaker three to four times with hexane-acetone $(9+1)$. The washings were decanted into the same evaporation flask. The combined extracts were evaporated on a rotation-type vacuum evaporator to a few milliliters. The evaporation residue was transferred quantitatively into a $10-\mathrm{ml}$ volumetric flask and filled up to the mark with hexane.

Experiment 2. The soil was treated as in Experiment 1 except that hexane was used as an extraction solvent.

Experiment 3. 50 to $100 \mathrm{~g}$ of soil was weighed into the extraction thimble of Soxhlet apparatus and extracted with about $250 \mathrm{ml}$ of hexane-acetone $(9+1)$ for 16 hours. The cooled mixture was filtered through a filter funnel containing about $20 \mathrm{~g}$ of anhydrous sodium sulphate into a 500-ml evaporation flask. The filtrate was evaporated on a rotation-type vacuum evaporator to a few milliliters. The evaporation residue was transferred into a $10-\mathrm{ml}$ volumetric flask and filled up to the mark with hexane.

Experiment 4. The soil was treated as in Experiment 3 except that $25 \%$ of water was added into the soil before extraction.

From these solutions 3 or $5 \mu \mathrm{l}$ were injected into the gas chromatograph. Comparing the results of these four esperiments it was found that extraction with hexane-acetone $(9+1)$ in Soxhlet (experiment 3) was the most effective. Comparing Experiments 1 and 2 it appeared that the mixture of hexane and acetone was a considerably more effective solvent than hexane (Tables 1 and 2).

Soil samples, number 5, were analysed according to the Experiments 3 and 4 . Addition of water onto the soil before extraction in Soxhlet did not influence the results.

All soil samples were determinated by the gas chromatograph both after extraction and after cleanup. The clean-up is described in detail in connection with the method. No essential differences were found in comparing the results of cleaned-up samples with the results of original samples. The clean-up of the extracts was not necessary for the gas chromatographic determination. The results are described in Tables 1 and 2.

All three gas chromatographic columne gave the same results.

The soil sample No. 19, in which the minimum residues were dound, was fortified with known quantities of p,p' -DDT, o,p' -DDT and p,p' -DDE and lindane standard solutions. The soil No. 14 was fortified with known quantities of endrin standard solution. These samples were then analysed as described above. The recoveries averaged from 90 to 100 per cent.

Method: 1. Pretreatment and extraction of samples. Dry the samples on paper at room temperature for 48 hours. Grind fine in a pounding trough and mix well. Weigh 50 or $100 \mathrm{~g}$ into extraction thimple of Soxhlet apparatus. Place a small plug of glass wool onto the sample and extract with $250 \mathrm{ml}$ of hexane-acetone $(9+1)$ for 16 hours. Filter the cooled solution through a filter funnel containing about $20 \mathrm{~g}$ of anhydrous sodium sulphate into a $500-\mathrm{ml}$ evaporation flask. Wash the extraction apparatus and the filter funnel three to four times with $30 \mathrm{ml}$ of hexane-acetone. Evaporate the combined filterates on a rotation-type vacuum evaporator to a few milliliters. Transfer evaporation residue quantitatively into a $10-\mathrm{ml}$ volumetric flask and fill up to the mark with hexane. Mix thoroughly.

2. Clean-up. Plug the end of the chromatographic column with a small portion of glass wool and follow with $4 \mathrm{~cm}$ of chromatographic mixture. Prewet the column with $20 \mathrm{ml}$ of methylene chloride. Close the stopcock when the methylene chloride is just above the adsorbent. Discard the methylene chloride solution.

Pipette $5 \mathrm{ml}$ of the sample solution in the $10-\mathrm{ml}$ volumetric flask into a small beaker. Evaporate to point of dryness with a compressor in a water bath $\left(30^{\circ} \mathrm{C}\right)$. Transfer the evaporation residue to the top of the column with $10 \mathrm{ml}$ of methylene chloride. Wash the beaker with $10 \mathrm{ml}$ of methylene chloride 
Table 1. Lindane and DDT (mg/kg), extracted from a soil sample (No. 9 in Table 3 ) by different solvents. Analysed by gas chromatographic column "Ethylene Glycol Adipate".

\begin{tabular}{|c|c|c|c|c|c|c|}
\hline & \multicolumn{2}{|c|}{$\begin{array}{l}\text { 1. Hexane-Acetone } \\
\text { over night }\end{array}$} & \multicolumn{2}{|c|}{ 2. Hexane over night } & \multicolumn{2}{|c|}{$\begin{array}{l}\text { 3. Hexane-Acetone in } \\
\text { Soxhlet }\end{array}$} \\
\hline & Original & Cleaned-up & Original & Cleaned-up & Original & Cleaned-up \\
\hline Lindane & $\begin{array}{l}0.0034 \\
0.004\end{array}$ & 0.006 & 0.002 & & 0.015 & 0.015 \\
\hline $\mathrm{p}, \mathrm{p}^{\prime}-\mathrm{DDT}$ & $\begin{array}{l}0.44 \\
0.52 \\
0.52 \\
0.60\end{array}$ & $\begin{array}{l}0.44 \\
0.60\end{array}$ & $\begin{array}{l}0.34 \\
0.30\end{array}$ & $\begin{array}{l}0.35 \\
0.30\end{array}$ & $\begin{array}{l}0.70 \\
0.84 \\
1.02\end{array}$ & $\begin{array}{l}0.85 \\
0.90 \\
0.95\end{array}$ \\
\hline $\mathrm{p}, \mathrm{p}^{\prime}-\mathrm{DDE}$ & $\begin{array}{l}0.02 \\
0.04 \\
0.04 \\
0.03\end{array}$ & 0.035 & 0.02 & 0.02 & $\begin{array}{l}0.05 \\
0.06 \\
0.04\end{array}$ & 0.05 \\
\hline $\mathrm{o}, \mathrm{p}^{\prime}-\mathrm{DDT}$ & $\begin{array}{l}0.08 \\
0.13 \\
0.13 \\
0.13\end{array}$ & 0.15 & 0.07 & 0.06 & $\begin{array}{l}0.15 \\
0.2 \\
0.2\end{array}$ & 0.2 \\
\hline
\end{tabular}

Table 2. Endrin ( $\mathrm{mg} / \mathrm{kg}$ ), extracted from four soil samples (numbers as in Table 3) by different solvents. Analysed by gas chromatographic column "SE-30".

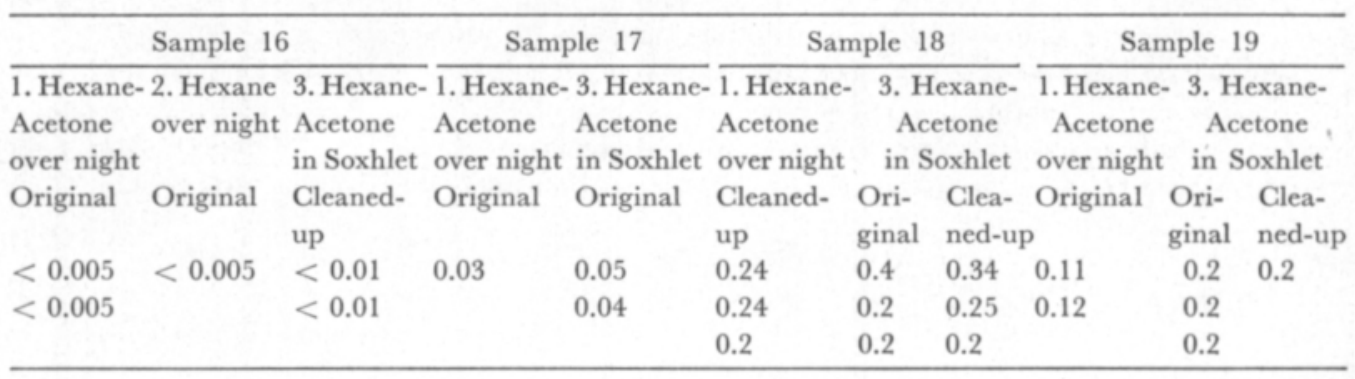

and add the washings to the column after the above mentioned solution has reached the top of the column. Eluate with $50 \mathrm{ml}$ of methylene chloride into a $150-\mathrm{ml}$ evaporation flask. Evaporate the eluate to about $1 \mathrm{ml}$ on a rotation-type vacuum evaporator.

Add $10 \mathrm{ml}$ of hexane and evaporate to a few drops. Repeat the addition of hexane and evaporation once more. Dissolve the evaporation residue in hexane and transfer with hexane into a test tube, graduated to $5 \mathrm{ml}$. Evaporate to the mark.

3. Determination of residue sample. Inject 3 or $5 \mu \mathrm{l}$ from both the original and cleaned-up soil extract into the gas chromatograph. Measure the heights of the peaks. Inject sample and standard solutions alternately. Compare the peak heights of sample solution with the peak heights of standard solutions.

4. Standard solutions. Weigh $10 \mathrm{mg}$ of pure standard solution in a weighing boat, dissolve in hexane and transfer into a $100-\mathrm{ml}$ volumetric flask. Fill up to the mark with hexane. From this 100 -ppm solution make such dilutions that their peak heights are near to the peak heights of sample solution. 


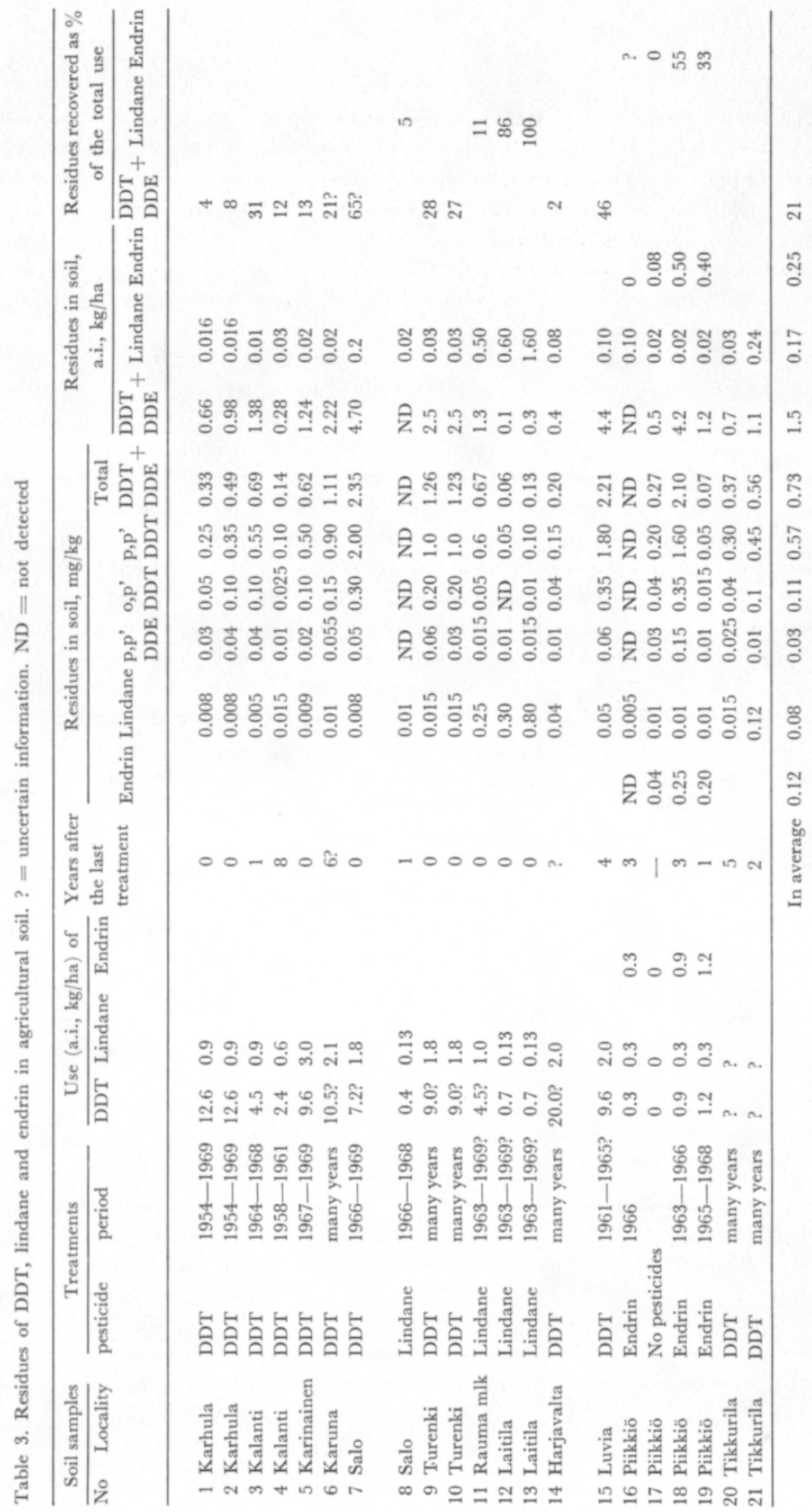


The DDT-content (o,p'-DDT + p,p'-DDT + p,p'-DDE) of the analysed soil samples was in average $0.73 \mathrm{ppm}$ (Table 3). On three samples the total amount of DDT exceeded $2 \mathrm{ppm}$, and on six samples $1 \mathrm{ppm}$. In samples from two sections (8 and 16) no DDT or DDE was found. The ratio between o,p' - DDT and p,p' - DDT in soil $(0.11$ and $0.57 \mathrm{ppm})$ represented roughly the mass ratio of the isomers in commercial preparations. The content of p,p'- DDE was in average $0.03 \mathrm{ppm}$ and the greatest value was $0.15 \mathrm{ppm}$ (No. 18). The amount of DDE was about $5 \%$ of the total of p,p' DDT and o,p' DDT together.

At the time when the samples were taken an average of $21 \%(\min .2 \%$ and $\max$. $65 \%$ ) was left of the total amount of DDT applied to the section.

There was no evident correlation to be found between the DDT-content of the soil and the amounts used or the time passed since the last treatment.

In all samples measurable amounts of lindane were detected. The average lindane content of the soil was $0.08 \mathrm{ppm}$ (min. 0.008 and max. $0.8 \mathrm{ppm}$ ). On sections where it was known that the seeds had been treated with lindane (Nos. 8, 11-13) the lindane content of the soil was greater (on an average $0.34 \mathrm{ppm}$ ) than on sections where lindane as far is known, had not been used at least not in the 1960 's $(0.028 \mathrm{ppm})$. However, the lindane content of the sample from section 8 was smaller $(0.01 \mathrm{ppm})$ than in the other three samples (Nos 11-13, the corresponding average being $0.45 \mathrm{ppm}$ ).

Of the amount of lindane, which was known to have been applied to the soil 5-100 $\%$ was left. From sample 13 more lindane was found than had according to the owner of the land been used during recent years.

The endrin content of only four sections (Nos. 16-19) was investigated. On the section where endrin had been used in 1966 no measurable amounts were found, but on section 17, which purposely had not been treated with pesticides, $0.04 \mathrm{ppm}$ of endrine was found. The average endrin content of the four samples was $0.12 \mathrm{ppm}$. From the total amount of endrin applied in the area $0-55 \%$ was left.

On the basis of these values it is possible to calculate the total amount of o,p' - DDT, p,p' - DDT and DDE in a layer of earth $(20 \mathrm{~cm}$ thick $=2$ million kilos $)$ in one hectare of land as being $1.5 \mathrm{~kg}(0-4.7 \mathrm{~kg})$. The corresponding value for lindane was $0.17 \mathrm{~kg}$ $(0.02-1.6 \mathrm{~kg})$ and endrine $0.25 \mathrm{~kg}(0-0.5 \mathrm{~kg})$.

No measurable amounts of PCB - compounds were found in these soil samples.

\section{CONCLUSIONS}

Soil samples were intentionally taken from areas where it was known that DDT, endrin, and lindane had been used for a long time and in great amounts. The amounts of DDT (DDT's + DDE) do not seem to correlate with the amounts used or with the period of time after the last treatment. The amount of organic matter hardly influences the dispersion of the results because the cultivated areas for sugarbeet were primarily in fine sand - silt soils in which the content of organic matter is low. The amounts of DDT + DDE found (mean $0.73 \mathrm{ppm}$ ) seem to belong to the same category as the amounts generally found in field soils (see e.g. EDWARDs 1966 and 1970). In garden soils on the 
other hand greater average DDT contents have been found; normally the average values have been some ppm's (op. cit.). For example in Norway, the average DDT + DDE content of garden soils was $10.1 \mathrm{ppm}$, the minimum being 3.7 and the maximum 17.3 ppm (Stenersen and Friestad 1969).

All analysed samples contained measurable amounts of lindane, also such samples where, according to the owner, lindane had never been used. In Finland the use of lindane has been concentrated on cultivations of cruciferous plants, but it is possible that during two decades on all investigated sections of the sugarbeet area some cruciferous plants, which have been treated with lindane, have been grown. The effects of treatments with lindane can be clearly seen in three sections (Nos. 11-13). On these sections the period between sowing and sample collection was about five months. The lindane content of number eight was almost comparable with the 'untreated' sections; about seventeen months, i.e. two summers, had passed since the sowing of the lindane-treated seeds.

WheATLey (1965) calculated on the basis of experiments over several years that annual treatment of soil with DDT will probably lead to the slow increase of the DDT content of soil. Treatment every two or three years would lead to an equilibrium, where the annual input and disappearence would be almost equal. The long winter of the northern areas could be expected in general to slow down the rate of disappearance of pesticides from soil. In Finland the soil stays frozen for about six months and the dissolution, transport and evaporation of pesticides cease almost entirely for that period of time. However, on the basis of this study it can not be concluded that the analysed pesticides would exceptionally accumulate in field soil. The DDT + DDE - content of all investigated sections corresponded to about 1.5 kilos per one hectare of matter, and in samples, where the treatments with DDT were known in detail (Nos. 1-7, 9, 10, 14, 15), the corresponding amount was about $1.9 \mathrm{~kg} /$ hectare. On these areas the annual application of DDT has been about 1.6 kilos, thus the DDT + DDE content of the soil has been at the time of sampling about $20 \%$ greater than the application rate.

A c know ledgements. We wish to express our best thanks to all the sugarbeet factories in Finland, as well as to the Dept. of Horticulture, Agricultural Research Centre, for making available the soil samples and for information on the use of pesticides in the analysed fields.

\section{REFERENCES}

Edwards, C. A. 1966. Insecticide residues in soil. Residue Rev. 13:83-132.

Edwards, C. A. 1970. Persistent pesticides in the environment. In "Critical reviews in environmental control" 1, 1:7-67. Publ. Chemical Rubber Co., Cleveland, Ohio, U.S.A.

Markivul, M. \& Tittanen, K. 1969. Pesticides in agriculture and forestry in Finland. Kemian Teollisuus 26, 10:817-822.

Stenersen, J. \& Friestad, H. O. 1969. Residues of DDT and DDE in soil from Norwegian fruit orchards. Acta Agric. Scand. 19:240-244.

WheAtley, G. A. 1965. The persistence, accumulation and behaviour of organochlorine insecticides in soil. Proc. 12th Int. Cong. Ent.: 556-557. 


\title{
SELOSTUS
}

\section{DDT:n, LINDAANIN JA ENDRIININ MÄÄRÄT VILJELYMAISSA}

\author{
JoRmA RAUTAPÄÄ \\ Maatalouden tutkimuskeskus, Tuhoeläintutkimuslaitos, Tikkurila \\ Hilkka Siltanen, Anna-Liisa Valta ja Veijo Mattinen \\ Valtion maatalouskemian laitos, Helsinki
}

DDT:tä ja lindaania on aikaisemmin käytetty yleisesti sokerijuurikkaan tuholaisten torjuntaan ja endriinillä on torjuttu myyriä puutarhoissa sekä metsäpuutaimistoissa. Koska näiden aineiden määristä viljelymaissa ei ollut tietoja, kerättiin syksyllä 1969 maanäytteet sellaisilta lohkoilta, joilla DDT:tä, lindaania tai endriiniä tiedettiin käytetyn pitkään.

Tutkittujen maanäytteiden DDT-pitoisuus oli keskimäärin $0.73 \mathrm{mg}$ maakilossa. Kolmella lohkolla DDT:n määrä oli suurempi kuin $2 \mathrm{mg} / \mathrm{kg}$ (maksimi $2.35 \mathrm{mg}$ ). Näytteitä otettaessa oli lohkolle joutuneen DDT:n kokonaismäärästä jäljellä noin $21 \%$ (ääriarvot 2 ja $65 \%$ ).

Kaikissa näytteissä todettiin jonkin verran lindaania. Keskiarvo oli $0.08 \mathrm{mg} / \mathrm{kg}$. Lohkoilla, joilla tiedettiin kylvetyn lindaanilla peitattua siementä, oli lindaanipitoisuus kymmenkertainen verrattuina lohkoihin, joilla kylvösiementä ei tiettävästi oltu peitattu. Maahan joutuneen lindaanin kokonaismäärästä oli jäljellä $5-100 \%$.

Neljän tutkitun maanäytteen endriinipitoisuus oli keskimäärin $0.12 \mathrm{mg} / \mathrm{kg}$. Alueella käytetystä endriinin kokonaismäärästä oli jäljellä $0-55 \%$.

DDT:n kokonaismääräksi (DDT + hajoamistuotteet) hehtaarin alan multakerroksessa $(20 \mathrm{~cm})$ arvioitiin $1.5 \mathrm{~kg}$. Lindaanin vastaava määrä oli $0.17 \mathrm{~kg}$ ja endriinin $0.25 \mathrm{~kg}$.

Tutkittujen lohkojen torjunta-ainepitoisuudet näyttävät jokseenkin samansuuruisilta kuin aineiden määrät vastaavissa viljelymaissa muualla Euroopassa tai Pohjois-Amerikassa. On arvioitu, että Suomea lämpimämmillä alueilla maan käsittely kerran vuodessa DDT:llä johtaisi DDT:n määrien vähittäiseen suurenemiseen ja käsittely joka toisena tai kolmantena vuonna saisi aikaan tasapainon, jonka aikana poistuma olisi yhtä suuri kuin lisäys. Tämän tutkimuksen perusteella ei näytä siltä, että Suomen pitkä talvi merkittävästi hidastaisi DDT:n, lindaanin tai endriinin poistumista maasta ja aiheuttaisi määrien vähittäisen suurenemisen. Tutkituilla alueilla oli maan DDT-pitoisuus yleensä samansuuruinen tai hieman suurempi kuin vuotuinen lisäys. 